Dorota Szczygiet*

Aleksandra Jasielska**

Agata Wytykowska***

\title{
Psychometric properties of the Polish version of the Trait Emotional Intelligence Questionnaire-Short Form
}

\begin{abstract}
The study was aimed at validating the Polish version of the Trait Emotional Intelligence Questionnaire-Short Form (TEIQue-SF). Our findings confirm the reliability and validity of the scale. With respect to reliability, internal consistency coefficients of the TEIQue-SF were comparable to those obtained using the original English version. The evidence of the validity of the TEIQue-SF came from the pattern of relations with the other self-report measure of EI, personality measures, as well as affective and social correlates. We demonstrated that the TEIQue-SF score correlated positively with scores on the Emotional Intelligence Questionnaire (INTE) (Jaworowska \& Matczak, 2001). The TEIQueSF score correlated negatively with Neuroticism and positively with Extraversion, Openness, Agreeableness, and Conscientiousness. In addition, scores on the TEIQue-SF were related to dispositional affect, i.e., correlated positively with positive affectivity and negatively with negative affectivity. The TEIQue-SF score correlated positively with social competencies as measured with the Social Competencies Questionnaire (Matczak, 2001). We also found that trait EI, as measured with the TEIQue-SF, was positively related to the richness of one's supportive social network and this relationship remained statistically significant even after controlling for Big Five variance. We also demonstrated that scoring on the TEIQue-SF was positively related to satisfaction with life and negatively related to perceived stress and these relationships remained significant, even after controlling for positive and negative affectivity. Taken together, these findings suggest that the Polish version of the TEIQue-SF is a reliable and valid measure that inherits the network of associations both from the original version of the TEIQue-SF and the full form of the Polish TEIQue (Wytykowska \& Petrides, 2007).
\end{abstract}

Key words: trait emotional intelligence, personality, dispositional affectivity, social functioning, TEIQue

\section{Introduction}

In the last years there has been a dramatic increase in research on emotional intelligence (EI). This research has strengthened and solidified our understanding that EI is crucial for various aspects of healthy adaptation, ranging from affective functioning to social relations (Jasielska \& Leopold, 2000; Matczak, 2007; Mayer, Salovey, \& Caruso, 2004; Ogińska-Bulik, 2005; Petrides, 2011; Szczygieł \& Kiełkiewicz, 2005). Consequently, the construct of EI has gained widespread academic acceptance and has found its place in all the major textbooks on the psychology of individual differences (Chamorro-Premuzic, Furnham, \& von Stumm, 2011; Cooper, 2010; Strelau, 2014).
A number of conceptualizations of EI have been proposed and they can be classified into two categories: ability models (e.g., Mayer \& Salovey, 1997) and trait models (e.g., Petrides \& Furnham, 2003). Ability EI is defined as the ability to perceive and express emotion, assimilate emotion in thought, understand emotion, and regulate emotion in oneself and others (Mayer \& Salovey, 1997), while trait EI is defined as a constellation of selfperceptions located at the lower levels of personality hierarchies (Petrides, Pita, \& Kokkinaki, 2007). Therefore, the former captures individuals' ability to use emotions and emotional knowledge (i.e., what a person is capable of doing), whereas the latter relates to people's selfperceptions of their emotional abilities and is intended to

\footnotetext{
* SWPS University of Social Sciences and Humanities, Poland

** Institute of Psychology, Adam Mickiewicz University, Poland

*** SWPS University of Social Sciences and Humanities, Poland
} 
capture what a person actually does (i.e., how much of these abilities manifest in practice) (Petrides \& Furnham, 2000).

The distinction between these two models is based exclusively on the method used to measure the construct and not on the features of EI that both models are assumed to cover (for discussion, see Petrides, 2011). Ability EI (or cognitive-emotional ability) is measured by performance tests relating to maximum-performance (Mayer, Salovey, Caruso, \& Sitarenios, 2003; Szczygieł, Buczny, \& Bazińska, 2013), whereas trait EI is assessed by self-report inventories referring to typical-performance (Petrides, 2011). Therefore, ability EI belongs to the domain of cognitive ability, while trait EI belongs to the realm of personality (Petrides, 2011).

These two models of EI are sometimes treated as competitors, however, both approaches have merits and should be acknowledged as complementary rather than contradictory (for discussion, see Ciarrochi, Chan, \& Caputi, 2000; McCrae, 2000; Mikolajczak, 2009). The distinction between trait and ability EI is now treated as a standard in the scientific literature, which helps to organize the accumulation of knowledge in the field (Austin $\&$ Saklofske, 2010; Petrides, 2011). In the present paper we refer to the trait EI model.

\section{Trait emotional intelligence}

The construct of trait EI defines EI as a constellation of emotional self-perceptions capturing the extent to which one is able to attend to, identify, understand, regulate, and utilize one's own and other people's emotions (Petrides, 2011). An alternative term to describe the construct is "trait emotional self-efficacy" (Petrides, 2011, p. 660). Understanding EI as a trait refers to the individual emotional dispositions, subjective perception of emotional experience and skills possessed by people in the areas relevant to EI. Such an approach positions trait EI outside the taxonomy of human cognitive ability (Carroll, 1993).

The concept of trait EI was derived from a content analysis of the literature on EI and related constructs, such as alexithymia, affective communication, emotional expression, and empathy (Petrides, 2009; Petrides \& Furnham, 2001, 2003). The aim was the inclusion of the crucial elements common to more than one model, but to eliminate peripheral elements appearing in only one specific conceptualization (Petrides \& Furnham, 2001). Thus, the concept of trait EI includes many features belonging to the area of personality, such as empathy, impulsiveness (low), assertiveness, emotionality, social intelligence (Thorndike, 1920), and intrapersonal intelligence (Gardner, 2001).

It should be emphasized that the relationship between trait EI and personality concerns primarily the emotional aspects of personality. Actually, the results of numerous studies demonstrate that Trait EI is mainly related to affectively saturated personality dimensions (Davies, Stankov, \& Roberts, 1998; Perez, Petrides, \& Furnham, 2005; Petrides \& Furnham, 2001).

The assumption that intelligence as a construct in psychology belongs to the realm of personality has been met with the objection that scores obtainable from the measures of intelligence are redundant with existing personality measures (Davies et al., 1998; Matthews, Roberts, \& Zeidner, 2004; Matthews, Zeidner, \& Roberts, 2002; McCrae, 2000). This controversy has led researchers to vital questions: Is trait EI distinguishable from wellestablished personality traits? Where is trait EI located in Eysenckian and Big Five taxonomies?

In order to clarify this issue, Petrides et al. (2007) conducted extensive research on the validity of the trait EI construct and demonstrated that trait EI encompasses two sources of variance: one portion of variance already covered by well established personality taxonomies (i.e., the Big Five or the Big Three) and one portion of variance that lies outside these dimensions. Petrides et al. (2007) showed that trait EI is a construct that lies at the lower levels of personality hierarchies, because it is distinct from the higher order factors described by both the Eysenck personality scales and the five-factor model scales.

Another approach to the problem of overlapping between trait EI and some personality traits is to examine the incremental validity of trait EI over and above personality in the prediction of outcome variables (Szczygieł, 2008). A growing number of studies have shown incremental trait EI effects over and above higherorder personality dimensions. For example, trait EI has been shown to have incremental validity in the prediction of coping, stress, and life satisfaction (Kluemper, 2008). Similarly, Freudenthaler, Neubauer, Gabler, Scherl and Rindermann (2008) demonstrated incremental validity of trait EI in the prediction of life satisfaction and somatic complaints. Van Der Zee and Wabeke (2004) observed that trait EI predicts additional variance over and above the Big Five in competency to support others.

Constituent elements of trait EI are: emotional perception, emotion expression, relationships, trait empathy, trait optimism, trait happiness, emotional management, assertiveness, social awareness, emotion regulation, impulsiveness (low), stress management, selfesteem, adaptability, self-motivation (Petrides, 2011; Wytykowska \& Petrides, 2007).

\section{Trait Emotional Intelligence Questionnaire (TEIQue)}

The Trait Emotional Intelligence Questionnaire (TEIQue; Petrides, 2009) is a self-report questionnaire that has been developed to cover the trait EI sampling domain comprehensively (Petrides \& Furnham, 2001). The TEIQue consists of 153 items to which participants respond on a 7-point scale and provides scores on 15 facets (a brief description of the facets is given in Table 1), 4 factors, and global trait EI (see Table 1). The process of construction and detailed psychometric analyses of the TEIQue are presented in Petrides (2009).

Studies employing the TEIQue have shown that individual differences in trait EI are associated with differences in conceptually related measures of adaptive coping styles and depressive affect (Mavroveli, Petrides, 
Rieffe, \& Bakker, 2007), happiness (Chamorro-Premuzic, Bennett, \& Furnham, 2007), leadership (Villanueva \& Sanchez, 2007), and affective decision - making (Sevdalis, Petrides, \& Harvey, 2007).

Results of several studies provide evidence that trait EI is a construct that allows for the assessment of individual differences in emotion regulation. Mikolajczak \& Luminet (2008) have demonstrated that individuals high in trait EI are both more likely to appraise stressful situations as a challenge (rather than a threat) and are more confident that they can cope with such situations. Hence, high trait EI would be expected to be protective against stress. There is indeed evidence supporting this prediction. Mikolajczak, Roy, Luminet, Fillee, \& de Timary (2007) observed that individuals high in trait EI (as compared to individuals low in trait EI) showed significantly lower reactivity to a stressful event (i.e., public speaking task) at both physiological (i.e., salivary cortisol) and psychological (i.e., mood deterioration) levels. Mikolajczak, Petrides, Coumans, \& Luminet (2009) observed that individuals high in trait EI reported a smaller increase in negative mood as a result of laboratory-induced stress than their low in EI study counterparts. The results of another study revealed that students high in trait EI appraised stressful events such as exam sessions as less threatening and displayed a lesser increase in psychological symptoms and somatic health complaints during exams than their low in trait EI counterparts (Mikolajczak, Luminet, \& Menil, 2006).
Studies employing the TEIQue have also shown that trait EI promoted the use of adaptive emotion regulation strategies (e.g., positive reappraisal) and prevented the choice of maladaptive emotion regulation strategies (e.g., self-blame) strategies in the case of anger, fear, jealously, stress and shame (Mikolajczak, Nelis, Hansenne, \& Quoidbach; 2008) There is also evidence that when confronted with stressful situations, unlike individuals low in trait EI, individuals high in trait EI are more likely to utilize coping styles which are generally regarded as adaptive (e.g., task-focused coping) rather than those that which are generally regarded as maladaptive (e.g., emotionfocused coping) (Bastian, Burns, \& Nettelbeck, 2005; Petrides, Pérez-González, \& Furnham, 2007; Saklofske, Austin, Galloway, \& Davidson, 2007). Szczygieł and Bazińska (2013) demonstrated that employees who declared greater intensity of negative emotions reported more symptoms of burnout, however, this effect was observed only among employees who were low in trait EI. Negative emotions and burnout were unrelated among employees who were high in trait EI.

These results suggest that the TEIQue is a reliable instrument to measure individual differences in trait EI and demonstrate that trait IE plays an important role in shaping and improving the efficiency of functioning and the quality of life of the individual. The TEIQue has been translated into 21 languages (for the full set of current translations, see http://www.teique.com), showing in all cases excellent

Table 1. The 15 facets of the TEIQue positioned with reference to their corresponding factor.

Note that adaptability and self-motivation ("auxiliary" or "independent" facets) are not keyed to any factor, but feed directly into the global trait EI score. Description of factors and facets of the TEIQue is based on: Petrides (2011)

\begin{tabular}{|c|c|c|}
\hline Factors & Facets & High scorers view themselves as ... \\
\hline \multirow{4}{*}{ Emotionality } & Empathy & capable of taking someone else's perspective \\
\hline & Emotional perception (self and others) & clear about their own and other people's feelings \\
\hline & Emotion expression & capable of communicating their feelings to others \\
\hline & Relationships & capable of maintaining fulfilling personal relationships \\
\hline \multirow{3}{*}{ Sociability } & Emotional management (others) & capable of influencing other people's feelings \\
\hline & Assertiveness & forthright, frank, and willing to stand up for their rights \\
\hline & Social awareness & accomplished networkers with superior social skills \\
\hline \multirow{3}{*}{ Self-control } & Emotion regulation & capable of controlling their emotions \\
\hline & Impulsiveness (low) & reflective and less likely to give in to their urges \\
\hline & Stress management & capable of withstanding pressure and regulating stress \\
\hline \multirow{3}{*}{ Well-being } & Optimism & confident and likely to "look on the bright side" of life \\
\hline & Happiness & cheerful and satisfied with their lives \\
\hline & Self-esteem & successful and self-confident \\
\hline \multirow{2}{*}{ Auxiliary facets } & Adaptability & flexible and willing to adapt to new conditions \\
\hline & Self-motivation & driven and unlikely to give up in the face of adversity \\
\hline
\end{tabular}


internal consistency. Detailed psychometric analyses of the TEIQue are presented in Freudenthaler et al. (2008; German adaptation), in Mikolajczak, Luminet, Leroy, and Roy (2007; French adaptation), and in Wytykowska and Petrides (2007; Polish adaptation). The psychometric properties of these instruments are comparable to characteristics of the TEIQue presented for the original English version (Petrides, 2009).

In addition to the full form, there is the TEIQue-short (TEIQue-SF). The TEIQue-SF consists of 30 items and is based on the full form. It includes two items from each of the 15 facets of the TEIQue. Items were selected primarily on the basis of their correlations with the corresponding total facet scores, which ensured broad coverage of the sampling domain. The TEIQue-SF can be used in research designs with limited experimental time. Although it is possible to derive scores on the four trait EI factors, in addition to the global score, these tend to have lower internal consistencies than in the full form. The TEIQue-SF does not yield scores on the 15 trait EI facets.

\section{The present study}

Research conducted by Wytykowska and Petrides (2007) demonstrated that the Polish version of the TEIQue is a psychometrically sound and valid measure of trait EI. The results showed that the TEIQue scores were normally distributed and reliable. The four-factor structure was replicated as well. The validity analyses reveled that the global TEIQue score predicts the level of depression, aggression and hostility. Importantly, trait IE, as measured with the Polish version of the TEIQue, was negatively related to depression, aggression and hostility beyond dispositional positive and negative affectivity. The results also showed that trait EI is positively related to life satisfaction beyond dispositional positive and negative affectivity. Global TEIQue score as well as the four factors were positively related to adaptive cognitive strategies of emotional regulation and task oriented coping style (for details see Wytykowska \& Petrides, 2007).

Our goal here was to develop and validate a Polish TEIQue-SF by testing whether the Polish TEIQue-SF would replicate prior findings concerning psychometric properties and relations to other constructs.

First, the psychometric properties of the Polish TEIQue-SF were examined. We expected the psychometric properties of the Polish TEIQue-SF to be comparable to characteristics of the TEIQue-SF presented for the original English version of the TEIQue-SF (Cooper \& Petrides, 2010).

Second, we expected scores on the TEIQue-SF to be positively related to scores on other measures of EI. We decided to use the Emotional Intelligence Questionnaire (INTE) (Jaworowska \& Matczak, 2001), which is a Polish version of a questionnaire developed by Schutte et al. (1998). INTE is a well established measure of EI and is based on the early three-branch EI model of Salovey and Mayer (1990): the appraisal and expression of emotion, the regulation of emotion, and the utilization of emotions in thinking and activity.
Third, associations with conceptually related constructs were examined, and predictions were formulated according to theoretical assumptions (Petrides, 2011) and prior findings (e.g., Cooper \& Petrides, 2010; Wytykowska $\&$ Petrides, 2007).

The first set of predictions concerned the relation with social competencies measures. The concept of social competency refers to complex skills that provide effective functioning in various social situations (Matczak, 2001). Matczak (2001) distinguished three types of social competencies: intimate competence, social exposition competence, and assertive competence. These skills are shaped during the social training process on the basis of personality, intellectual, and emotional features of which the essential one is EI (Matczak \& Martowska, 2011; Martowska, 2014). Thus, we expected trait EI to be positively related to social competencies.

A second set of predictions concerned the relation with affective and personality measures. We expected trait EI to be positively associated with the experience of positive mood and negatively associated with the experience of negative mood. In a similar vein, we expected trait EI to be related to the affectively saturated personality dimensions of Extraversion and Neuroticism (Pytlik Zillig, Hemenover, \& Dienstbier, 2002). Specifically, we predicted trait EI to be negatively related to Neuroticism and positively related to Extraversion. Also, based on prior empirical findings (Mikolajczak et al., 2007; Wytykowska \& Petrides, 2007), we expected trait EI to be positively related to Openness, Agreeableness, and Conscientiousness - however, given that these personality dimensions are less affectively saturated (Pytlik Zillig et al., 2002), we expected these relations to be rather modest in size.

Finally, the aim of the study was to examine the incremental validity of trait EI. As discussed in the previous section, due to the conceptual correspondences between trait EI and personality, incremental validity studies focus primarily on whether trait EI explains criterion variance over and above personality.

First, we expected trait EI to be related to the ability to build and maintain a supportive social network. Salovey, Bedell, Detweiler, and Mayer (1999) argue that emotionally intelligent individuals are more likely to gain access to rich social support networks and that they are more likely to rely on these networks during times of stress. We examined both trait EI and Big Five personality traits as predictors of the ability to build and maintain a supportive social network because both trait EI and personality traits are likely to influence social behaviors and the quality of social relations (Lopes, Salovey, \& Straus, 2003; Salovey et al., 1999). Thus, we expected trait EI to explain the supportive social network of an individual over and above the variance accounted for by the Big Five.

Second, we expected trait EI to be associated with satisfaction with life (Diener, Emmons, Larsen, Griffin, 1985) and perceived stress (Cohen, Kamarck, \& Mermelstein, 1983) over and above positive and negative affectivity. Life satisfaction refers to the individual's global judgment on his or her life as a whole and it is an important 
indicator of subjective well-being. Previous research shows positive associations between trait EI and life satisfaction (e.g., Saklofske, Austin, \& Minski, 2003). It was also demonstrated that high trait EI is associated with lower levels of stress (e.g., Petrides \& Furnham, 2006). Thus, we predicted trait EI to be positively related to satisfaction with life and inversely related to perceived stress. However, we assessed the TEIQue-SF incremental validity for stress and satisfaction with life, putting it against positive and negative affectivity (mood).

\section{The structure of the research results presentation}

The study was conducted in 4 groups (samples) due to the different variables that were analyzed in each sample. Participants were recruited from students of Poznan University of Medical Sciences (Sample A, $N=100$ ), Gdansk University of Technology (Sample B, $N=100$ ), University of Gdansk (Sample C, $N=150$ ), Medical University of Gdansk (Sample D, $N=140$ ). A variety of recruitment methods and incentives were used, including advertising through social network sites, word of mouth, and course data collection. All participants completed the TEIQue-SF and other instruments (depending on the sample; this is discussed further in the next section). Most of the questionnaires were completed in group sessions (15 to 25 people), i.e., during supervised class sessions, although some were completed in participants' own time. The whole procedure, depending on the sample, lasted about 10 to $30 \mathrm{~min}$. Participants were volunteers and no remuneration was offered for their participation in the study. The combined sample consisted of 490 participants. In this group psychometric properties of the TEIQue-SF were examined. For clarity in communicating research results, we first present the psychometric properties of the TEIQue-SF (data coming from the combined sample, $N=490$ ). Next, we present the results concerning the correlations of trait EI with other constructs. A different construct is analyzed in each of the samples. Therefore, the results obtained in each sample are presented separately.

\section{The psychometric properties of the TEIQue-SF}

\section{Participants}

The sample consisted of 490 students (51.2\% women). The participants' ages ranged from 18 to 29 years $(M=22.69 ; S D=2.40)$.

\section{Measures}

The Trait Emotional Intelligence QuestionnaireShort Form consists of 30 items designed to measure global trait emotional intelligence (e.g., "I usually find it difficult to regulate my emotions"; "I'm usually able to influence the way other people feel"). While preparing the Polish version of the TEIQue-SF, we used the same items that were included in the English version. The inclusion of the same items is due to two reasons. First, both full versions (English and Polish) show similar psychometric characteristics (see Wytykowska \& Petrides,
2007). Secondly, we wanted to create a tool with which it would be possible to compare the results obtained in other countries and, what is even more interesting, to conduct joint research in the future (Jasielska, 2014). The TEIQueSF uses a Likert-style response option format, ranging from 1 (completely disagree) to 7 (completely agree). A global trait EI score is calculated by summing up the item scores (after reverse scoring for negative items) and dividing by the total number of items. This global EI score can then be used to locate individuals' position in the trait continuum. The higher the score, the higher the trait EI of the individual. The Polish version of the TEIQue-SF is presented in Appendix.

\section{Results}

Descriptive statistics (e.g., means, standard deviations, range, skewness, and kurtosis) were used to analyze the data. Table 2 shows the mean, standard deviation, Cronbach's alpha, skewness, and kurtosis values for the global score of the TEIQue-SF, separately for women and men (for comparison, table 2 includes also the results obtained in the English study, see Cooper \& Petrides, 2010, Study 1, p. 451). An independent samples t test revealed that women scored significantly higher on the TEIQueSF than men, $\mathrm{t}(448)=3.36, \mathrm{p}<.0001$, but with a rather small effect size $(d=0.30)$. Cronbach's alpha values were high for both women and men. According to Curran, West, and Finch (1996), kurtosis and skewness absolute values of 0 to 7 , and 0 to 2 , respectively, can be considered as demonstrating sufficient univariate normality (see also Cooper \& Petrides, 2010). The female and male kurtosis and skewness values for the global TEIQue-SF score are presented in Table 2. As we can see, the psychometric properties of Polish and original, English version of the TEIQue-SF are alike.

\section{The TEIQue-SF and other self-report measures of emotional intelligence (Sample A)}

In this sample we examined the association between the TEIQue-SF and the Emotional Intelligence Questionnaire (INTE) (Jaworowska \& Matczak, 2001).

\section{Participants}

This sample consisted of 100 students whose age ranged from 18 to 27 years of age $(M=20.25 ; S D=1.97$; $47 \%$ women) of Poznan University of Medical Sciences (Faculty of Health Sciences).

\section{Measures}

The Trait Emotional Intelligence Questionnaire-Short Form (as described above).

The reliability in this sample was alpha $=.89$. The average result was: $M=4.99, S D=0.79$.

Emotional Intelligence Questionnaire (INTE) is a self-report questionnaire of EI (Jaworowska \& Matczak, 2001). INTE is a one-factor scale, consisting of 33 items. After summarizing the scores of the 5-point Likert scales, 
Table 2. Mean, standard deviation, Cronbach's $\alpha$, skewness, and kurtosis values for the Polish and the English versions of the TEIQue-SF.

\begin{tabular}{lcccc}
\hline & \multicolumn{2}{c}{ Global trait EI } \\
\cline { 2 - 5 } & \begin{tabular}{c} 
Men \\
\cline { 2 - 5 }
\end{tabular} & Polish version & English version* \\
\hline$M$ & 4.83 & $\begin{array}{c}\text { Women } \\
(\mathrm{N}=251)\end{array}$ & $\begin{array}{c}\text { Men } \\
(\mathrm{N}=455)\end{array}$ & $(\mathrm{N}=653)$ \\
\hline$S D$ & 0.79 & 5.06 & 5.02 & 5.18 \\
\hline Range & $2.67-6.93$ & 0.70 & 0.73 & 0.68 \\
\hline Cronbach's $\alpha$ & 0.90 & $2.73-6.63$ & $2.47-6.73$ & $2.80-6.80$ \\
\hline Skewness & -0.06 & 0.87 & 0.89 & 0.88 \\
\hline Kurtosis & -0.01 & -0.42 & -0.43 & -0.42 \\
\hline
\end{tabular}

*Cooper \& Petrides, 2010, Study 1, p. 451.

where $1=$ strongly disagree and 5 = strongly agree, we determined the perceived level of EI of the participant. The possible score range is between 33 and 165 . Validity and reliability of the Polish version of the scale have been well documented (Jaworowska \& Matczak, 2001). The reliability in this sample was alpha $=.86$. The average result was: $M=120.54, S D=11.98$.

\section{Results}

As expected, EI, as measured with the TEIQue-SF was positively related to Emotional Intelligence Questionnaire (INTE): $r=0.44 ; p<0.001$. Given that no changes were found in the results due to gender, the group was treated as one sample. The same approach was used in subsequent samples.

\section{The TEIQue-SF and social competencies (Sample B)}

The aim of this part of the study was to investigate the relationship between the TEIQue-SF and social competencies measures.

\section{Participants}

This sample consisted of 100 students whose age ranged from 20 to 26 years of age $(M=23.02 ; S D=1.35$; $50 \%$ women) of Gdansk University of Technology (Faculty of Engineering Management, Section of Humanistic Sciences and Managerial Communication).

\section{Measures}

The Trait Emotional Intelligence Questionnaire-Short Form (as described above).

The reliability in this sample was alpha $=.88$. The average result was: $M=5.01, S D=0.72$.

The Social Competencies Questionnaire (Matczak, 2001) is a self-descriptive measure of social competencies. The questionnaire comprises of 90 items, including 60 diagnostic ones (referring to social activities and tasks) and 30 non- diagnostic ones (referring to non-social skills). Respondents assess their rate of coping with those tasks on a four-level scale: very good, quite good, rather poor and very poor. The diagnostic items of the questionnaire make up three subscales: competencies that determine effective functioning in intimate situations - intimate competence (e.g., "Hugging a person who needs consolation"), competencies that determine effective functioning in situations requiring social exposition - social exposition competence (e.g., "Speaking in public"), competencies that determine effective functioning in situations requiring assertiveness - assertive competence (e.g., "Refusing to lend money to a friend"). The results in three subscales are calculated by summing up the item scores. We also calculated an overall score of social competence, involving the results obtained in all 60 diagnostic items. The average overall result was: $M=176.6, S D=21.1$. The average results in intimate competence, social exposition competence, and assertive competence were $M=43.83, S D=5.79, M=53.02, S D$ $=9.01$, and $M=48.23, S D=6.62$, respectively. The internal consistency reliability (Cronbach's $\alpha$ ) for the overall score was .94 and for the three subscales ranged from .79 to .91 .

\section{Results}

As expected, the TEIQue-SF score was positively related to intimate competence $(r=.37 ; p<.001)$, social exposition competence $(r=.55 ; p<.001)$, assertive competence $(r=.77 ; p<.001)$, as well as, to overall score of the Social Competencies Questionnaire $(r=.55 ; p<.001)$.

\section{The TEIQue-SF and ability to build and maintain a supportive social network - over and above personality traits (Sample C)}

The aim of this part of the study was twofold. Firstly, we investigated the relationship between the TEIQue-SF and Big Five personality traits. Secondly, we examined the TEIQue-SF's incremental validity in the prediction of the ability to build and maintain a supportive social network, putting it against personality traits. 


\section{Participants}

This sample consisted of 150 students whose age ranged from 19 to 29 years of age $(M=23.71 ; S D=2.02$; $56 \%$ women) of University of Gdansk (they came from various faculties, i.e., Biology, Economy, Law and Administration).

\section{Measures}

The Trait Emotional Intelligence Questionnaire-Short Form (as described above).

The Personality Inventory NEO-FFI by Costa and McCrae (1992; Polish adaptation: Zawadzki, Strelau, Szczepaniak, \& Śliwińska, 1998) was used to measure personality traits. It comprises of 60 items, 12 for each of the five dimensions of adult personality: Neuroticism, Extraversion, Openness to Experience, Agreeableness, and Conscientiousness. Items are rated on a 5-point-Likert scale ranging from absolutely false to absolutely true. The results in personality dimensions are calculated by summing up the item scores.

The Social Support and Social Ties Scale (SSSTS; in Polish: Skala Więzi i Wsparcia Społecznego; Skarżyńska, 2002). The SSSTS is a 6-item questionnaire that assesses perceived social support and social ties (e.g. "I can count on my friends in important matters for me", "Around me I have a lot of people who are close to me"). Items are rated on a 5-point-Likert scale ranging from 1 (definitely disagree) to 5 (definitely agree). The SSSTS score is calculated by summing up the item scores and dividing the sum by the total number of items.

\section{Results}

The means, standard deviations, and internal consistencies of the measures are presented in Table 3.

In line with the theoretical conceptualization of EI as a personality trait, we observed correlations between trait
EI and the NEO-FFI (Table 2). Trait EI was negatively correlated with Neuroticism and positively associated with Extraversion, Openness, Agreeableness, and Conscientiousness. It is noteworthy that trait EI correlates more strongly with Extraversion and Neuroticism.

As predicted, trait EI was significantly related to the richness of the supportive social network $(r=.55, p<.001$; see Table 2). To provide a more conservative test of this relationship, we predicted that trait EI is related to supportive social network beyond the Big Five personality test and this prediction was tested with two multiple regression analyses. The results showed that personality traits, which were entered in the first step of the regression equation explained $40 \%$ of the variance. However, only Extraversion and Agreeableness were significantly associated with social network support $(\beta=.52, p<.001$ and $\beta=.25, p<.001$, respectively). Beyond these control variables, trait EI was significant as a predictor of a supportive social network $(\beta=.35, p<.001)$, explaining an additional $5.6 \%$ of the unique variance. Therefore, our predictions were supported.

\section{The TEIQue-SF and satisfaction with life and perceived stress - over and above mood (Sample D)}

The aim of this part of the study was to examine the relationship between the TEIQue-SF and mood (dispositional affect). In addition, this study investigates the incremental validity of trait EI in relation to satisfaction with life and perceived stress, since mood variance has also been seen as a baseline that trait EI must exceed in criterion prediction (Petrides et al., 2007).

\section{Participants}

This sample consisted of 140 students whose age ranged from 19 to 29 years of age ( $M=23.09 ; S D=2.48 ; 50 \%$ women) of Medical University of Gdansk (Faculty of Pharmacy).

Table 3. Means, standard deviations, scale reliabilities, and intercorrelations among all study variables (Sample C)

\begin{tabular}{|c|c|c|c|c|c|c|c|}
\hline Variables & 1 & 2 & 3 & 4 & 5 & 6 & 7 \\
\hline 1. Trait emotional intelligence & - & & & & & & \\
\hline 2. Extraversion & $.50 * * *$ & - & & & & & \\
\hline 3. Neuroticism & $-.65 * * *$ & $-.31 * * *$ & - & & & & \\
\hline 4. Openness & $.30 * * *$ & $.21 * *$ & $-.18 *$ & - & & & \\
\hline 5. Conscientiousness & $.43 * * *$ & $.23 * *$ & $-.36 * * *$ & .05 & - & & \\
\hline 6. Agreeableness & $.29 * * *$ & .11 & $-.33 * * *$ & .03 & $.22 * *$ & - & \\
\hline 7. Supportive social network & $.55 * * *$ & $.58 * * *$ & $-.36 * * *$ & .15 & $.20^{*}$ & $.34 * * *$ & - \\
\hline Alpha & .90 & .80 & .85 & .80 & .82 & .79 & .81 \\
\hline$M$ & 5.01 & 30.68 & 19.51 & 28.45 & 31.85 & 28.97 & 3.97 \\
\hline$S D$ & .76 & 6.56 & 8.39 & 5.42 & 6.96 & 6.14 & .63 \\
\hline
\end{tabular}

$* \mathrm{p}<.05 ; * * \mathrm{p}<.01 ; * * * \mathrm{p}<.001$ (all two-tailed significance tests) 


\section{Measures}

The Trait Emotional Intelligence Questionnaire-Short Form (as described above).

The Satisfaction with Life Scale (SWLS; Diener et al., 1985; Polish adaptation: Juczyński, 2001) was used to measure the participants' satisfaction with life. The SWLS is an instrument designed to measure global cognitive judgments of satisfaction with one's life and an overall evaluation of the person's life. The questionnaire consists of five statements to which the respondent assigns a value from 1 (unsatisfied) to 7 (satisfied). The SWLS score is calculated by summing up the item scores.

The Perceived Stress Scale-10 (PSS-10; Cohen et al., 1983; Polish adaptation: Juczyński \& Ogińska-Bulik, 2009) was used to measure the degree to which one perceives one's life as stressful. The questionnaire is a short form of the evaluation of subjective feelings connected with personal events and issues during the previous month. The participants are asked to indicate their judgments by circling the frequency of their feelings or certain thoughts, for example, "In the last month how often have you been able to control irritations in your life?" The general result reflects the intensity of perceived stress. Participants indicate their answers on a 5-point scale ranging from 0 (never) to 4 (very often). The PSS-10 score is calculated by summing up the item scores.

The Positive and Negative Affect Schedule (PANAS: Watson, Clark, \& Tellegen, 1988) is the most frequently used instrument to assess dispositional positive and negative affectivity. It has been translated into several languages and has demonstrated robust psychometric properties (Polish validation by Brzozowski, 2010). The PANAS is a 20 -item scale which consists of 10 positive and 10 negative adjectives describing emotional states (e.g., active, excited, nervous, scared, distressed, etc.). Participants are asked, "To what extent do you generally feel this way, on average, across all situations?"). Participants indicate their answers on a 5-point scale ranging from 1 (very slightly or not at all) to 5 (extremely).
For each subscale, the score is calculated by summing up the item scores. The Positive Affect scale reflects the level of pleasant affective states, whereas the Negative Affect scale reflects a general dimension of negative affective states and distress.

\section{Results}

The means, standard deviations, and internal consistencies of the measures are presented in Table 4.

In line with our predictions trait EI was associated with dispositional affect. Specifically, we observed that trait EI correlated positively with positive affectivity and negatively with negative affectivity.

As predicted, trait EI was significantly related to satisfaction with life $(r=.31, p<.001$; see Table 4$)$. As a more conservative test of this relationship, we examined whether trait EI is related to satisfaction with life beyond dispositional affectivity. We tested this prediction with two multiple regression analyses. The results revealed that positive affectivity and negative affectivity, which were entered in the first step of the regression equation, were both significantly related to satisfaction with life $(\beta=.17$, $p<.05$ and $\beta=-.19, p<.05$, respectively), explaining $6 \%$ of the variance. Beyond these control variables, trait EI was significant as a predictor of satisfaction with life $(\beta=.24, p<.05)$, explaining an additional $3 \%$ of the unique variance. Therefore, our prediction was supported.

As predicted, trait EI was significantly related to perceived stress $(r=-.55 ; p<.001$; see Table 3$)$. As a more conservative test of this relationship, we examined whether trait EI is related to perceived stress beyond dispositional affectivity. We tested this prediction with two multiple regression analyses. The results revealed that positive affectivity and negative affectivity, which were entered in the first step of the regression equation, were both significantly related to perceived stress $(\beta=-.35, p<.001$ and $\beta=.46, p<.001$, respectively), explaining $38 \%$ of the variance. Beyond these control variables, trait EI was significant as a predictor of perceived stress $(\beta=-.35$, $p<.01)$, explaining an additional $3,1 \%$ of the unique variance. Therefore, our prediction was supported.

Table 4. Means, standard deviations, scale reliabilities, and intercorrelations among all study variables (Sample D)

\begin{tabular}{|c|c|c|c|c|c|}
\hline Variables & 1 & 2 & 3 & 4 & 5 \\
\hline 1. Trait emotional intelligence & - & & & & \\
\hline 2. Positive affectivity & $.59 * * *$ & - & & & \\
\hline 3. Negative affectivity & $-.46 * * *$ & $-.17 *$ & - & & \\
\hline 4. Satisfaction with life & $.31 * * *$ & $.20 *$ & $-.22 * *$ & - & \\
\hline 5. Perceived stress & $-.55^{* * *}$ & $-.43 * * *$ & $.52 * * *$ & $-.41 * * *$ & - \\
\hline Alpha & .89 & .87 & .89 & .83 & .93 \\
\hline$M$ & 4.82 & 31.92 & 18.71 & 21.52 & 17.48 \\
\hline$S D$ & .75 & 6.46 & 6.63 & 4.98 & 6.79 \\
\hline
\end{tabular}

$* \mathrm{p}<.05 ; * * \mathrm{p}<.01 ; * * * \mathrm{p}<.001$ (all two-tailed significance tests) 


\section{Discussion}

Our findings confirm the reliability and validity of the Polish version of the TEIQue-SF. With respect to reliability, internal consistency coefficients of the TEIQue-SF were comparable to those obtained using the original English version (Table 2; see also Cooper \& Petrides, 2010). The evidence of the validity of the TEIQue-SF came from the pattern of relations with the other self-report measure of EI, personality measures, as well as affective and social correlates.

We demonstrated that scores on the TEIQue-SF were positively related to scores on the Emotional Intelligence Questionnaire (INTE) (Jaworowska \& Matczak, 2001). The association between the TEIQue-SF and INTE was significant, albeit not very strong (see the Results section in the description of Sample A). We need to remember, however, that INTE is based on the three-branch EI model (Salovey \& Mayer, 1990), which includes three categories: appraisal and expression of emotions, regulation of emotions, and utilization of emotions in solving problems, whereas the TEIQue is based on a more complex conceptualization of EI and offers comprehensive coverage of the 15 facets of EI sampling domain. Therefore, the moderate correlation between the TEIQue-SF and INTE is quite understandable. It is worth noting that a similar result was obtained by Wytykowska and Petrides, who examined the relationship between INTE and full version of the TEIQue (see Wytykowska \& Petrides, 2007, p. 106, Table 5).

As it was mentioned earlier, trait EI is defined as a constellation of self-perceptions located at the lower levels of personality hierarchies (Petrides et al., 2007). Hence, trait EI is not distinct from personality constructs, but part of them. Consequently, we found correlations between trait EI and Big Five personality traits (Table 3). Trait EI was negatively associated with Neuroticism and positively associated with the Extraversion, Openness, Agreeableness, and Conscientiousness. Neuroticism was the strongest correlate of trait EI, followed by Extraversion, Conscientiousness, Agreeableness, and Openness. We expected such effects, as the trait EI conceptually overlaps mainly with the affectively saturated personality dimensions. Almost identical results were obtained in two Dutch samples (Petrides et al., 2010, Table 1, p. 907). A similar pattern of correlations was observed when the full version of the TEIQue was related to Big Five personality dimensions (see Wytykowska \& Petrides, 2007, p. 106, Table 5).

Next, we tested relations with another measure of affective functioning, i.e., dispositional affectivity. As expected, trait scores on the TEIQue-SF were related to greater positive and lesser negative emotion experience (see Table 4). This means that individuals high in trait EI are more likely to experience positive affect and less likely to experience negative affect than their low in EA counterparts. These results are consistent with those from the English sample (Petrides et al, 2007) and data collected in a French-speaking population (Mikolajczak et al., 2007).
We also examined the relationships of the TEIQueSF with social functioning. As predicted, the TEIQue-SF score correlated positively with social competencies that determine effective functioning in intimate situations, in situations requiring social exposition, as well as in situations requiring assertiveness. We expected such results, because EI has been cited as pivotal for effective and adaptive coping with situational challenges and is recognized as a necessary prerequisite for social competencies development (Matczak, 2001, 2007; Lopes et al., 2003; Salovey et al., 1999).

Going further, it is possible, that individuals high in EI - due to their high social competencies - are more likely to build and maintain solid social ties. Therefore, we tested the association of the TEIQue-SF score with the perceived richness of the supportive social network, as measured with the Social Support and Social Ties Scale (Skarżyńska, 2002). As expected, trait EI was positively related to the richness of the supportive social network (see Table 3). Of importance, this relationship remained statistically significant even after controlling for Big Five variance.

Finally, we demonstrated that trait EI is positively related to satisfaction with life and negatively related to perceived stress (see Table 4). This means that individuals high in trait EI are more likely to perceive their life as more satisfying and less stressful. Importantly, the relationships between trait EI and both satisfaction with life and perceived stress remained significant, even after controlling for positive and negative affectivity.

\section{Does trait emotional intelligence depend on gender?}

Common knowledge and wide-spread beliefs suggest that women are more emotional than men. This conventional wisdom has been supported by findings indicating that women tend to be more emotionally expressive, have greater emotional knowledge, and they have more interpersonal skills (Ciarrochi, Hynes, \& Crittenden, 2005; Fila-Jankowska \& Szczygieł, 2004; Szczygieł, 2007; Szczygieł \& Kolańczyk, 2002). Consequently, most studies of EI that include gender in their analysis have assumed women to be the more emotionally intelligent of the genders (e.g., Brackett \& Mayer, 2003; Ciarrochi et al., 2000). Our findings revealed such a difference between men and women in the TEIQue-SF, with women scoring higher (see Table 2). The difference is significant, albeit small in magnitude. This result is consistent with the findings obtained with the English version of the TEIQue-SF (Cooper \& Petrides, 2010). We need to remember, however, that studies using the TEIQue-SF refer only to global trait EI and do not allow us to draw conclusions about the differences between men and women in terms of specific facets of trait EI.

Trait EI is a multifaceted construct that comprises of fifteen emotion-related behavioral dispositions, which are thought to affect the ways an individual copes with emotional demands. Given the diversity of the facets, which are encompassed by trait EI, one may expect there to be areas in which women are superior to men and areas in which men are superior to women. This is exactly what 
the research shows when the full version of the TEIQue is used. Wytykowska and Petrides (2007) conducted research in a Polish sample and observed that women scored higher on Emotionality while man scored higher on Self-control. Similar gender differences were found in a French study (Mikolajczak et al., 2007), with women scoring higher on Emotionality and men scoring higher on Self-Control and Sociability. Thus, studies using the full version of TEIQue refute the claim that women 'in general' have greater emotional intelligence. An old Polish proverb, which says that 'the devil is in the detail' seems to be very true for gender differences in EI (for discussion concerning gender differences in trait EI see: Mikolajczak et al., 2007; Petrides \& Furnham, 2010).

\section{Limitations and future research}

The present study presents findings concerning the psychometric properties of a short version of the TEIQueSF. The TEIQue-SF seems to be a very useful research tool for trait EI due to its brevity and good psychometric properties demonstrated in numerous countries. Our findings provide evidence that the TEIQue-SF is a valid and reliable scale for the measurement of trait EI. However, the present research has two notable limitations. First, this study used a sample of university students. Future studies will need to test the generalizability of these findings using samples representing a wider age range, including older adults. Research findings also show the impact of age on EI an its facets, e.g., emotion regulation (Jasielska \& Szczygieł, 2007; Kadzikowska-Wrzosek, 2012; Szczygieł, 2007; Szczygieł \& Jasielska, 2008). Second, this study used a relatively circumscribed set of measures of affective and social functioning. In future research, it will be important to extend this set of measures. Therefore, the scale presented in this article should be considered as an experimental version of the TEIQue-SF.

\section{Concluding comment}

The concept of EI been proposed almost 25 years ago in the scientific literature. Ever since it has attracted intense interest both in the academic world and applied domains. The idea that people differ in their ability to recognize, understand, and manage emotions is theoretically appealing and practically relevant. However, ever since its occurrence this scientific domain has been characterized by vigorous debates on how this construct should be conceptualized, and especially how it could be assessed in a valid and reliable manner. In November 2014, The European Association of Psychological Assessment has organized at Ghent University Autumn School on the Assessment of Emotional Intelligence/Competence. During the autumn school recent scientific developments in the assessment of emotional intelligence were presented. A large part of the meeting was devoted to a discussion on the conceptualization and the measurement of trait EI. The Trait Emotional Intelligence Questionnaire has been recognized as a psychometrically sound instrument, which can be used in clinical, work, and school contexts. We believe that the brevity of the TEIQue-SF and its accumulating reliability and validity evidence makes this instrument a reasonable choice for those that are seeking a brief self-report measure of global EI.

\section{References}

Austin, E.J., \& Saklofske, D.H. (2010). Introduction to the special issue. Australian Journal of Psychology, 62 (1), 1-4. doi:10.1080/ 00049530903312832

Bastian, V.A., Burns, N.R., \& Nettelbeck, T. (2005). Emotional intelligence predicts life skills, but not as well as personality and cognitive abilities. Personality and Individual Differences, 39, 1135-1145. doi:org/10.1016/j.paid.2005.04.006

Brackett, M.A., \& Mayer, J.D. (2003). Convergent, discriminant, and incremental validity of competing measures of emotional intelligence. Personality and Social Psychology Bulletin, 29, 1147-1158. doi:10.1177/0146167203254596

Brzozowski, P. (2010). Skala uczuć pozytywnych i negatywnych SUPIN [Scale of Positive and Negative Experience SPANE]. Warszawa: Pracownia Testów Psychologicznych Polskiego Towarzystwa Psychologicznego.

Carroll, J.B. (1993). Human cognitive abilities: A survey of factor-analytic studies. New York: Cambridge University Press.

Chamorro-Premuzic, T., von Stumm, S., \& Furnham, A. (Eds.) (2011). The Wiley-Blackwell Handbook of Individual Differences. New York: Wiley.

Chamorro-Premuzic, T., Bennett, E., \& Furnham, A. (2007). The happy personality: Mediational role of trait emotional intelligence. Personality and Individual Differences, 42, 1633-1639. doi:10.1016/j. paid.2006.10.029.

Ciarrochi, J., Chan, A., \& Caputi, P. (2000). A critical evaluation of the emotional intelligence construct. Personality and Individual Differences, 28, 539-561. doi:10.1016/S0191-8869(99)00119-1

Ciarrochi, J., Hynes, K., \& Crittenden, N. (2005). Can men do better if they try harder: Sex and motivational effects on emotional awareness. Cognition and Emotion, 19, 133-141. doi:10.1080 /02699930441000102.

Cohen, S., Karmarck, T., \& Mermelstein, R. (1983). A global measure of perceived stress. Journal of Health and Social Behaviour, 24, 385-396. doi:10.2307/2136404

Cooper, A., \& Petrides, K. V. (2010). A psychometric analysis of the Trait Emotional Intelligence Questionnaire - Short Form (TEIQue - SF) using item response theory. Journal of Personality Assessment, 92, 449-457. doi:10.1080/00223891.2010.497426

Cooper, C. (2010). Individual Differences and Personality. London: Hodder Education.

Costa, P.T. Jr., \& McCrae, R.R. (1992). Revised NEO Personality Inventory (NEO-PI-R) and NEO Five-Factor Inventory (NEO-FFI). Professional manual. Odessa, FL: Psychological Assessment Resources.

Curran, P.J., West, S.G., \& Finch, J.F. (1996). The robustness of test statistics to nonnormality and specification error in confirmatory factor analysis. Psychological Methods, 1, 16-29. doi: 10.1037/1082989X.1.1.16

Davies, M., Stankov, L., \& Roberts, R. D. (1998). Emotional intelligence: In search of an elusive construct. Journal of Personality and Social Psychology, 75, 989-1015. doi:10.1037/0022-3514.75.4.989

Diener, E., Emmons, R. A., Larsen, R. J., \& Griffin, S. (1985). The satisfaction with life scale. Journal of Personality Assessment, 49, 71-75. doi: org/10.1207/s15327752jpa4901_13

Fila-Jankowska, A., \& Szczygieł, D. (2004). Wptyw pomiaru pobudzenia fizjologicznego na deklarowana intensywność emocji - różnice między ptciami [The impact of monitoring parameters of emotional arousal on declared intensity of emotions - sex differences]. Psychologia Jakości Życia, 3 (2), 165-182.

Freudenthaler, H.H., Neubauer, A.C., Gabler, P., Scherl, W.G., \& Rindermann, H. (2008). Testing and validating the trait emotional intelligence questionnarire (TEIQue) in a German-speaking sample. Personality and Individual Differences, 45, 673-678. doi:org/10.1016/j. paid.2008.07.014

Gardner, H. (2001). Creators: Multiple intelligences. In K.H. Pfenninger, \& V.R. Shubik (Eds.), The origins of creativity (pp. 117-144). New York: Oxford University Press. 
Jasielska, A. (2014). Women's career success in a man's workplace a cross-national study. Romanian Journal of Experimental Applied Psychology, 5(1), 23-32.

Jasielska, A., \& Leopold, M.A. (2000). Kompetencja a inteligencja emocjonalna - pojęcia tożsame czy różne? [Emotional competence versus emotional intelligence - the same or different concepts?]. Forum Oświatowe, 23, 5-32.

Jasielska, A., \& Szczygieł, D. (2007). Funkcjonowanie emocjonalne osób w okresie późnej dorosłości na przykładzie regulacji emocji [Emotional regulation as an example of emotional functioning in the late adulthood]. Psychologia Rozwojowa, 12 (2), 61-74.

Jaworowska, A., \& Matczak, A. (2001). Kwestionariusz Inteligencji Emocjonalnej INTE N.S. Schutte, J.M. Malouffa, L.E. Hall, D.J. Haggerty'ego, J.T. Cooper, C.J. Guldena i L. Dornheim [INTE emotional intelligence questionnaire by N.S. Schutte, J.M. Malouff, L.E. Hall, D.J. Haggerty, J.T. Cooper, C.J. Golden, and L. Dornheim]. Warszawa: Pracownia Testów Psychologicznych Polskiego Towarzystwa Psychologicznego.

Juczyński, Z. (2001). Narzędzia pomiaru w promocji i psychologii zdrowia [Tools of measurement in the promotion and psychology of health]. Warszawa: Pracownia Testów Psychologicznych Polskiego Towarzystwa Psychologicznego.

Juczyński, Z., Ogińska-Bulik, N. (2009). Narzędzia pomiaru stresu $i$ radzenia sobie ze stresem [Instruments for measurement of stress and coping]. Warszawa: Pracownia Testów Psychologicznych.

Kadzikowska-Wrzosek, R. (2012). Perceived stress, emotional ill-being and psychosomatic symptoms in high school students: the moderating effect of self-regulation competences. Archives of Psychiatry and Psychotherapy, 3, 25-33.

Kluemper, D.H. (2008). Trait emotional intelligence: The impact of coreself evaluations and social desirability. Personality and Individual Differences, 44, 1402-1412. doi: org/10.1016/j.paid.2007.12.008

Lopes, P.N., Salovey, P., \& Straus, R. (2003). Emotional intelligence, personality, and the perceived quality of social relationships. Personality and Individual Differences, 35, 641-658. doi:org/10.1016/ S0191-8869(02)00242-8

Martowska, K. (2014). Temperamental Determinants of Social Competencies. Polish Psychological Bulletin, 45(2), 128-133. doi:10.2478/ ppb-2014-0017

Matczak, A. (2001). Kwestionariusz Kompetencji Spolecznych [The Social Competence Questionnaire]. Warszawa: Pracownia Testów Psychologicznych Polskiego Towarzystwa Psychologicznego.

Matczak, A. (2007). Rola Inteligencji emocjonalnej [The role of emotional intelligence]. Studia Psychologiczne, 45(1), 9-18.

Matczak, A., \& Martowska, K. (2011). Z badań nad uwarunkowaniami kompetencji emocjonalnych [From research on determinants of emotional competence]. Studia Psychologica, 11, 5-18.

Matthews, G., Roberts, R.D., \& Zeidner, M. (2004). Seven myths about emotional intelligence. Psychological Inquiry, 15, 179-196. doi org $/ 10.1207 / \mathrm{s} 15327965$ pli1503 01

Matthews, G., Zeidner, M., \& Roberts, R.D. (2002). Emotional intelligence: Science and myth. Cambridge, MA: MIT Press.

Mavroveli, S., Petrides, K.V., Rieffe, C., \& Bakker, F. (2007). Trait emotional intelligence, psychological well - being and peer - rated social competence in adolescence. British Journal of Developmental Psychology, 25, 263-275. doi:org/10.1348/026151006X118577

Mayer, J.D., \& Salovey, P. (1997). What is emotional intelligence? In P. Salovey, \& D. Sluyter (Eds.), Emotional development and emotional intelligence: Educational implications (pp. 3-31). New York: Basic Books.

Mayer, J.D., Salovey, P., Caruso, D. R. (2004). Emotional Intelligence: Theory, Findings, and Implications. Psychological Inquiry, 15, 197-215. doi:org/10.1207/s15327965pli1503 02.

Mayer, J.D., Salovey, P., Caruso, D.R., \& Sitarenios, G. (2003). Measuring emotional intelligence with the MSCEIT V 2.0. Emotion, 3, 97-105. doi:10.1037/1528-3542.3.1.97.

McCrae, R.R. (2000). Emotional intelligence from the perspective of the five-factor model of personality. In: R. Bar-On \& J.D.A. Parker (Eds.), The handbook of emotional intelligence (pp. 261-276). San Francisco: Jossey-Bass.

Mikolajczak, M., \& Luminet, O. (2008). Trait emotional intelligence and the cognitive appraisal of stressful events: An exploratory study. Personality and Individual Differences, 44, 1445-1453. doi:org/10.1016/j.paid.2007.12.012

Mikolajczak, M., Luminet, O., \& Menil, C. (2006). Predicting resistance to stress: Incremental validity of trait emotional intelligence over alexithymia and optimism. Psicothema, 18, 79-88.

Mikolajczak, M., Luminet, O., Leroy, C., \& Roy, E. (2007). Psychometric properties of the trait emotional intelligence questionnaire: Factor structure, reliability, construct, and incremental validity in a Frenchspeaking population. Journal of Personality Assessment, 88, 338353. doi: org/10.1080/00223890701333431

Mikolajczak, M., Menil, C., \& Luminet, O. (2007). Explaining the protective effect of trait emotional intelligence regarding occupational stress: Exploration of emotional labor processes. Journal of Research in Personality, 41, 1107-1117. doi:org/10.1016/j. jrp.2007.01.003

Mikolajczak, M., Nelis, D., Hansenne, M., \& Quoidbach, J. (2008). If you can regulate sadness, you can probably regulate shame: Associations between trait emotional intelligence, emotion regulation and coping efficiency across discrete emotions. Personality and Individual Differences, 44, 1356-1368. doi: org/10.1016/j.paid.2007.12.004

Mikolajczak, M., Petrides, K.V., Coumans, N., \& Luminet, O. (2009). The moderating effect of trait emotional intelligence on mood deterioration following laboratory-induced stress. International Journal of Clinical and Health Psychology, 9(3), 455-477.

Mikolajczak, M., Roy, E., Luminet, O., Fillee, C., \& de Timary, P. (2007) The moderating impact of emotional intelligence on free cortisol responses to stress. Psychoneuroendocrinology, 32, 1000-1012. doi: org/10.1016/j.psyneuen.2007.07.009

Ogińska-Bulik, N. (2005). Emotional intelligence in the workplace: exploring its effects on occupational stress and health outcomes in human service workers. International Journal Occupational Medicine and Environmental Health, 18(2), 167-175.

Pérez, J.C., Petrides, K.V., \& Furnham, A. (2005). Measuring trait emotional intelligence. In R. Schulze and R.D. Roberts (Eds.), International Handbook of Emotional Intelligence. Cambridge, MA Hogrefe \& Huber.

Petrides, K.V., \& Furnham, A. (2003). Trait emotional intelligence: Behavioural validation in two studies of emotion recognition and reactivity to mood induction. European Journal of Personality, 17, 39-57. doi:org/10.1002/per.466

Petrides, K.V. (2009). Technical manual for the Trait Emotional Intelligence Questionnaires (TEIQue). London: London Psychometric Laboratory.

Petrides, K.V. (2011). Ability and trait emotional intelligence. In: T. Chamorro-Premuzic, A. Furnham, \& S. von Stumm (Eds.), The WileyBlackwell Handbook of Individual Differences (pp. 656-678). New York: Wiley.

Petrides, K.V., \& Furnham, A. (2000). Gender differences in measured and self-estimated trait emotional intelligence. Sex Roles, 42(5-6), 449-461. doi: org/10.1023/A:1007006523133

Petrides, K.V., \& Furnham, A. (2000). On the dimensional structure of emotional intelligence. Personality and Individual Differences, 29, 313-320. doi:org/10.1016/S0191-8869(99)00195-6

Petrides, K. V., \& Furnham, A. (2001). Trait emotional intelligence: Psychometric investigation with reference to established trait taxonomies. European Journal of Personality, 15, 425-448. doi: org/10.1002/per.416

Petrides, K.V., \& Furnham, A. (2003). Trait emotional intelligence: Behavioural validation in two studies of emotion recognition and reactivity to mood induction. European Journal of Personality, 17, 39-57. doi:org/10.1002/per.466

Petrides, K.V., \& Furnham, A. (2006). The role of trait emotional intelligence in a gender-specific model of organizational variables. Journal of Applied Social Psychology, 36, 552-569. doi: org/10.1111/ j.0021-9029.2006.00019.x

Petrides, K.V., Pérez-González, J.C, \& Furnham, A. (2007). On the criterion and incremental validity of trait emotional intelligence. Cognition \& Emotion, 21, 26-55. doi:org/10.1080/02699930601038912

Petrides, K.V., Pita, R., \& Kokkinaki, F. (2007). The location of trait emotional intelligence in personality factor space. British Journal of Psychology, 98, 273-289. doi:org/10.1348/000712606X120618

Petrides, K.V., Vernon, P.A., Schermer, J.A., Ligthart, L., Boomsma, D.I., \& Veselka, L. (2010). Relationships between trait emotional intelli- 
gence and the Big Five in the Netherlands. Personality and Individual Differences, 48, 906-910. doi: org/10.1016/j.paid.2010.02.019

Pytlik Zillig, L.M., Hemenover, S.H., \& Dienstbier, R.A. (2002). What do we assess when we assess a big 5 trait? A content analysis of the affective, behavioral and cognitive processes represented in the big 5 personality inventories. Personality and Social Psychology Bulletin, 28(6), 847-858. doi: org/10.1177/0146167202289013

Saklofske, D.H., Austin, E.J., \& Minski, R.S. (2003). Factor structure and validity of a trait emotional intelligence measure. Personality and Individual Differences, 34, 707-721. doi:org/10.1016/S01918869(02)00056-9

Saklofske, D.H., Austin, E.J., Galloway, J., \& Davidson, K. (2007). Individual difference correlates of health-related behaviors: Preliminary evidence for links between emotional intelligence and coping. Personality and Individual Differences, 42, 491-502. doi:org/10.1016/j. paid.2006.08.006

Salovey, P., \& Mayer, J.D. (1990). Emotional intelligence. Imagination, Cognition, and Personality, 9, 185-211. doi: 0.2190/DUGG-P24E52WK-6CDG

Salovey, P., Bedell, B., Detweiler, J.B., \& Mayer, J. (1999). Coping intelligently: emotional intelligence and the coping process. In C.R. Snyder (Ed.), Coping: the psychology of what works (pp. 141-164). New York: Oxford University Press.

Schutte, N.S., Malouff, J.M., Hall, L.E., Haggerty, D.J., Cooper, J.T., Golden, C.J., \& Dornheim, L. (1998). Development and validation of a measure of emotional intelligence. Personality \& Individual Differences, 25, 167-177. doi: doi.org/10.1016/S01918869(98)00001-4

Sevdalis, N., Petrides, K.V., \& Harvey, N. (2007). Trait emotional intelligence and decision - related emotions. Personality and Individual Differences, 42, 1347-1358. doi:org/10.1016/j.paid.2006.10.012

Skarżyńska, K. (2002). Zaufanie, więzi społeczne i poczucie skuteczności a życie w demokracji. Psychologiczne predyktory satysfakcji z życia i sukcesu we współczesnej Polsce [Trust, social ties and self-efficacy and life in a democracy. Psychological predictors of life satisfaction and success in contemporary Poland]. Kolokwia Psychologiczne, 10, 199-211.

Strelau, J. (2014). Różnice indywidualne. Historia-determinanty-zastosowania [Individual differences. History-determinants-application]. Warszawa: Wydawnictwo SCHOLAR.

Szczygieł, D. (2007). Zdolniejsze kobiety czy mniej zmotywowani mężczyźni? Różnice między płciami w zróżnicowaniu i złożoności werbalizacji emocji [Sex differences in complexity and differentiation of verbalization of emotions - ability or motivation?]. Psychologia, Edukacja i Spoleczeństwo, 4 (1), 47-66.

Szczygieł, D. (2008). Inteligencja emocjonalna - więcej niż IQ i osobowość? O potrzebie i znaczeniu sprawdzania trafności dodanej narzędzi mierzacych inteligencję emocjonalna [Emotional Intelligence - more than IQ and personality? The need and the im- portance of testing incremental validity of emotional intelligence instruments]. In M. Śmieja \& J. Orzechowski (Eds.), Inteligencja emocjonalna: fakty, mity, kontrowersje [Emotional intelligence: Facts, myths, controversies] (pp. 136-152). Warszawa: PWN.

Szczygieł, D., \& Bazińska, R. (2013). Emotional intelligence as a moderator in the relationship between negative emotions and emotional exhaustion among employees in service sector occupations. Polish Psychological Bulletin, 44(2), 75-86. doi: 10.2478/ppb-2013-0023

Szczygieł, D., \& Jasielska, A. (2008). Czy z wiekiem stajemy się bardziej inteligentni emocjonalnie? Przetwarzanie informacji o emocjach w wieku młodzieńczym i średniej dorosłości (Age differences in emotional intelligence- are we getting better? Processing of emotional information in adolescence and mature age]. Psychologia Rozwojowa, 13 (1), 85-99.

Szczygieł, D., \& Kiełkiewicz J. (2005). Inteligencja emocjonalna i powodzenie szkolne [Emotional intelligence and emotional intelligence and academic achievement]. Psychologia Rozwojowa, 10 (1), $59-68$.

Szczygieł, D., \& Kolańczyk, A. (2000). Skala Poziomów Świadomości Emocji. Adaptacja Skali Levels of Emotional Awareness Scale Lane'a i Schwartza [The Polish adaptation of the Levels of Emotional Awareness Scale]. Roczniki Psychologiczne, 3, 155-179.

Szczygieł, D., Buczny, J., \& Bazińska, R. (2012). Emotion regulation and emotional information processing: The moderating effect of emotional awareness. Personality and Individual Differences, 52, 433-437. doi: http://dx.doi.org/10.1016/j.paid.2011.11.005

Thorndike, E.L. (1920). Intelligence and its uses. Harper's Magazine, 140, 227-235.

Van Der Zee, K., \& Wabeke, R. (2004). Is trait-emotional intelligence simply or more than just a trait? European Journal of Personality, 18, 243-263. doi:org/10.1002/per.517

Villanueva, J.J., \& Sanchez, J.C. (2007). Trait emotional intelligence and leadership self-efficacy: Their relationship with collective efficacy. The Spanish Journal of Psychology, 10, 349-357.

Watson, D., Clark, L.A., \& Tellegen, A. (1988). Development and validation of brief measures of positive and negative affect: The PANAS scales. Journal of Personality and Social Psychology, 54, 10631070. doi:10.1037/0022-3514.54.6.1063

Wytykowska, A., Petrides, K.V. (2007). Inteligencja emocjonalna jako dyspozycja. Polska adaptacja skali do badania inteligencji emocjonalnej jako cechy [Polish adaptation of the Trait Emotional Intelligence Questionnaire (TEIQue)]. Psychologia, Edukacja i Spoteczeństwo, 4, 97-110.

Zawadzki, B., Strelau, J., Szczepaniak, P., \& Śliwińska, M. (1998). Inwentarz osobowości NEO-FFI Costy i McCrae. Podręcznik [Personality Inventory NEO-FFI by Costa and McCrae. Polish Adaptation. Handbook]. Warszawa: Pracownia Testów Psychologicznych Polskiego Towarzystwa Psychologicznego. 


\section{APPENDIX \\ TEIQue-SF, Polish version}

Odpowiedz na poniższe pytania, zakreślając ten numer, który najlepiej oddaje Twój stosunek do podanych stwierdzeń. Do dyspozycji masz siedem możliwych odpowiedzi, które zawierają się między dwiema skrajnymi opiniami: $1=$ zupełnie nie $-7=$ absolutnie tak. Nie ma odpowiedzi dobrych ani złych, ponieważ każdy człowiek jest inny i ma indywidualny stosunek do zaprezentowanych stwierdzeń. Staraj się pracować szybko, nie zastanawiaj się zbyt nad odpowiedziami, pierwsza odpowiedź jest najlepsza. Spróbuj udzielać możliwie jak najbardziej precyzyjnych odpowiedzi.

\begin{tabular}{|c|c|c|c|c|c|c|c|}
\hline 1. Nie mam problemu z wyrażaniem uczuć za pomocą słów. & 1 & 2 & 3 & 4 & 5 & 6 & 7 \\
\hline 2. Często sprawia mi trudność spojrzenie na coś z czyjegoś punktu widzenia.(R) & 1 & 2 & 3 & 4 & 5 & 6 & 7 \\
\hline 3. Ogólnie jestem osobą z silną motywacją. & 1 & 2 & 3 & 4 & 5 & 6 & 7 \\
\hline 4. Zazwyczaj nie potrafię zapanować nad swoimi uczuciami.(R) & 1 & 2 & 3 & 4 & 5 & 6 & 7 \\
\hline 5. W zasadzie życie nie wydaje mi się zabawne.(R) & 1 & 2 & 3 & 4 & 5 & 6 & 7 \\
\hline 6. Potrafię wszystko z ludźmi załatwić. & 1 & 2 & 3 & 4 & 5 & 6 & 7 \\
\hline 7. Często zmieniam zdanie.(R) & 1 & 2 & 3 & 4 & 5 & 6 & 7 \\
\hline 8. Często zdarza mi się, że nie wiem, co właściwie czuję.(R) & 1 & 2 & 3 & 4 & 5 & 6 & 7 \\
\hline 9. Czuję, że mam wiele zalet. & 1 & 2 & 3 & 4 & 5 & 6 & 7 \\
\hline 10. Często jest mi trudno bronić swoich praw.(R) & 1 & 2 & 3 & 4 & 5 & 6 & 7 \\
\hline 11. Zazwyczaj potrafię wpływać na to, co inni czują. & 1 & 2 & 3 & 4 & 5 & 6 & 7 \\
\hline 12. W gruncie rzeczy moje spojrzenie na większość rzeczy jest $\mathrm{p}$ & 1 & 2 & 3 & 4 & 5 & 6 & 7 \\
\hline 13. Moi bliscy często skarżą się, że nie traktuję ich dobrze.(R) & 1 & 2 & 3 & 4 & 5 & 6 & 7 \\
\hline 14. Często mam kłopoty, żeby dostosować się do zewnętrznych okoliczności.(R) & 1 & 2 & 3 & 4 & 5 & 6 & 7 \\
\hline 15. W zasadzie wiem, jak radzić sobie ze stresem. & 1 & 2 & 3 & 4 & 5 & 6 & 7 \\
\hline 16. Często trudno mi okazywać uczucia moim najbliższym.(R) & 1 & 2 & 3 & 4 & 5 & 6 & 7 \\
\hline $\begin{array}{l}\text { 17. Zazwyczaj potrafię wczuć się w sytuację innych ludzi i doświadczać tych } \\
\text { samych uczuć. }\end{array}$ & 1 & 2 & 3 & 4 & 5 & 6 & 7 \\
\hline 18. Trudno mi motywować samego siebie.(R) & 1 & 2 & 3 & 4 & 5 & 6 & 7 \\
\hline $\begin{array}{l}\text { Zwykle udaje mi się znaleźć sposób, żeby zapanować nad swoimi emocjami, } \\
\text { o ile tylko tego chcę. }\end{array}$ & 1 & 2 & 3 & 4 & 5 & 6 & 7 \\
\hline 20. Ogólnie jestem zadowolony ze swojego życia. & 1 & 2 & 3 & 4 & 5 & 6 & 7 \\
\hline 21. Uważam się za dobrego negocjatora. & 1 & 2 & 3 & 4 & 5 & 6 & 7 \\
\hline $\begin{array}{l}\text { 22. Mam skłonność do angażowania się w rzeczy, z których chciał(a)bym się } \\
\text { póziej wycofać.(R) }\end{array}$ & 1 & 2 & 3 & 4 & 5 & 6 & 7 \\
\hline 23. Często zastanawiam się nad tym co dokładnie czuję & 1 & 2 & 3 & 4 & 5 & 6 & 7 \\
\hline 24. Wierzę w to, że mam wiele mocnych stron. & 1 & 2 & 3 & 4 & 5 & 6 & 7 \\
\hline 25. Zwykle ustępuję, nawet jeśli wiem, że mam rację.(R) & 1 & 2 & 3 & 4 & 5 & 6 & 7 \\
\hline 26. Wydaje mi się, że nie mam żadnego wpływu na uczucia innych ludzi.(R) & 1 & 2 & 3 & 4 & 5 & 6 & 7 \\
\hline 27. W zasadzie wierzę w to, że moje życie dobrze się ułoży. & 1 & 2 & 3 & 4 & 5 & 6 & 7 \\
\hline $\begin{array}{l}\text { 28. Sprawia mi trudność ułożenie sobie stosunków nawet z tymi, którzy są mi } \\
\text { najbliżsi.(R) }\end{array}$ & 1 & 2 & 3 & 4 & 5 & 6 & 7 \\
\hline 29. Zwykle potrafię przystosować się do nowego otoczenia & 1 & 2 & 3 & 4 & 5 & 6 & 1 \\
\hline 30. Zazwyczaj potrafię się wyluzować. & 1 & 2 & 3 & 4 & 5 & 6 & 7 \\
\hline
\end{tabular}

(R) - reverse scoring 